\title{
Business Model Research: From Concepts to Theories
}

\author{
Susan Lambert ${ }^{1} \&$ Marco Montemari $^{2}$ \\ ${ }^{1}$ Adelaide Institute of Higher Education, Australia \\ ${ }^{2}$ Department of Management, School of Economics “G. Fuà”, Università Politecnica delle Marche, Ancona, \\ Italy \\ Correspondence: Marco Montemari, Department of Management, School of Economics "G. Fuà", Università \\ Politecnica delle Marche, Piazzale Martelli, 8 - 60121 Ancona, Italy. E-mail: m.montemari@univpm.it
}

Received: August 10, 2017

doi:10.5539/ijbm.v12n11p41

\begin{abstract}
The purpose of this paper is threefold. Firstly, it provides business model researchers with a structured analysis of the research that is required to enable business model theories to be developed. A schema for analyzing existing research and for discerning the research required to move towards business model theory building is proposed. The importance of conceptual research along with deductive and inductive empirical research is emphasized. Secondly, the extant business model literature is analyzed according to the research schema to highlight current gaps in the research and the progress being made towards theorization. Thirdly, opportunities for future research are identified and thematically categorized to encourage progressive cycles of conceptual-deductive-inductive research and ultimately, theorizing. The need for business model theory building, both in relation to the business model concept per se and concerning the relationships between business models and other phenomena, is the basis of this article.
\end{abstract}

Keywords: business models, research schema, theory building, classification, research agenda

\section{Introduction}

From the mid to late nineteen-nineties, during the dot com era, the term 'business model' became extremely popular as a field of study (Fielt, 2013; Zott, Amit, \& Massa, 2011). Although there is still no universally accepted definition, a consensus seems to be gradually moving towards the one that describes the business model as the framework through which enterprises execute their strategy (McGrath, 2010; Nielsen, Roslender, \& Bukh, 2009; Nielsen \& Montemari, 2012), thus enabling our understanding of how value is actually created and captured (Osterwalder \& Pigneur, 2010; Teece, 2010). The business model concept makes it possible to conceive an enterprise as a set of interrelated choices regarding its main strategic elements, including the value proposition, along with the key activities, resources and partners needed to develop it, as well as the target customers and the channels and relationships required to reach them (Morris, Schindehutte, \& Allen, 2005). Thus, the business model concept enables managers and entrepreneurs to clearly understand the value creation process and to identify the value drivers, the organizational issues, and the strategic challenges that emerge as strategy is being implemented (Montemari \& Chiucchi, 2017).

In light of its usefulness, much has been written about business models. Practitioners and researchers alike are keen to discover which business models work best in various circumstances and settings (Gassmann, Frankenberger, \& Csik, 2014), which ones generate the highest profits (Zott \& Amit, 2007), are sustainable (Bocken, Short, Rana, \& Evans, 2014), and are adaptable (Chesbrough, 2007; Sabatier, Mangematin, \& Rousselle, 2010). Furthermore, there is interest in identifying tools, solutions, frameworks, and managerial practices to support business model innovation (Taran, Nielsen, Montemari, Thomsen, \& Paolone, 2016) and in predicting what happens when parts of the business model change or what happens to the business model when extant forces change (Cavalcante, 2013; Demil \& Lecocq, 2010).

Despite practitioners and researchers having embraced the business model concept, considerable research is still needed if the business model itself is to endure. In this relatively young research field a major challenge is to place 'the business model in a theoretical perspective where it can be understood in more abstract terms and then applied in new ways' (Arend 2013, p. 390). This challenge requires business model theories to be developed and tested.

This paper proposes a theoretical framework in the form of a schema and analyses business model research 
according to that schema. The types of research present in the literature are identified along with the research required to advance towards business model theory building. Next, the extant business model literature is analyzed and classified according to the proposed research schema to determine the current gaps in the research and the progress being made towards theorization. Lastly, opportunities for future research are identified and thematically categorized to encourage progressive cycles of conceptual-deductive-inductive research and ultimately, theorizing. This finally leads the authors to summarize the main implications of the paper for business model research.

\section{The Theoretical Framework}

\subsection{What is Theory?}

Researchers differ in their acceptance of what counts as theory and therefore, they define theory differently. For example;

A theory is a statement of relations among concepts within a set of boundary assumptions and constraints. It is no more than a linguistic device used to organize a complex empirical world (Bacharach 1989, p.496).

A theory is a set of systematically interrelated concepts, definitions and propositions that are advanced to explain and predict phenomena (facts) (Cooper \& Schindler 2000, p.51).

A theory is basically an explanation (Berg \& Lune, 2012), i.e., a general and more or less comprehensive set of statements that explain different aspects of a phenomenon (Silverman, 2006). The breadth of the explanation can be used as a yardstick to distinguish different kind of theories. Some scholars take a liberal view of theorizing (Llewelyn, 2003) and others take a narrow and restrictive perspective commonly adopted in natural sciences where theory is viewed as consisting of universal statements capable of falsification (Popper, 1959). These universal theories, often referred to as 'grand theories', develop general explanations for a discipline or a body of knowledge. Grand theories play a crucial role in knowledge development, but they address concepts at a highly abstract level and therefore tend to oversimplify complex issues (Ayres, 2008). In contrast to grand theories, mid-range theories are context-bound, the findings relating to particular classes of objects rather than all such objects. Mid-range theories are useful for analysing practice disciplines, like business model research, because they are both concrete enough to explain the context-bound phenomena under analysis and abstract enough to be applied to contexts beyond the one in which they were developed (Morgan \& Wildemuth, 2009). Mid-range theories of business models are context-bound since they are intended to hold true under particular circumstances and for particular categories of business models rather than for all contexts or for all instances of business models. These theories are based on generalizations about business models that take the results of inductive empirical research and infer general patterns of configurations of business model variables. The generalizations are one step away from theorizing; they form the basis of theories and provide input for further conceptualizations.

Generalization can be bound by factors external to the business model, such as the industry in which the business model functions; empirical research that is industry specific immediately limits generalizations to the industry context. Generalization can also be bound by factors internal to the business model; such generalizations bound by the internal characteristics of the business model must rely on a classification of business models based on those characteristics.

In all forms of scientific research, including the organizational sciences (McKelvey, 1982) and behavioural sciences (Mezzich \& Solomon, 1980), the classification of objects is an important step towards theorizing because 'theory cannot explain much if it is based on an inadequate system of classification' (Bailey 1994, p. 15). Classifications '(....) are partway between a simple concept and a theory. They help to organise abstract, complex concepts' (Neuman 2003, p. 46). As business models are abstract and complex concepts (Lambert, 2015), our understanding of them can be improved through the development of a general classification scheme. To enable generalizations to be made about classes of business models, a general classification scheme that identifies homogeneous classes of business models and allows for the comparison between heterogeneous classes is required. More particularly, the development of mid-range business model theories requires a classification scheme from which generalizations about business models, their components, and the relationships among those components can be inferred.

Empirical research plays a central role in classifications in that it is used either to validate conceptually derived classes (deductive research that proposes typologies) or it is used to determine the classes (inductive research that generates taxonomies). Typologies are designed deductively by categorizing objects into predefined groups which are created through intuition and/or with reference to existing theory (Doty \& Glick, 1994). Typologies 
consider only a few (usually only two or three) characteristics to determine the types of objects, thus rendering them useful for specific purposes, but limiting their usefulness for other purposes and providing a basis for only limited generalizations (Lambert, 2015). In contrast, taxonomies are generated inductively through statistical analysis and they can simultaneously consider a large number of variables (Steininger et al. 2013, referring to Bailey 1994). 'A taxonomy can serve as a general classification of objects from which generalizations can be made, hypotheses proposed, and eventually mid-range theory generated... [because the categories (taxa) of taxonomies are derived inductively]... based on the totality of their observable characteristics' (Lambert 2015, p.53). Thus, taxonomical research is needed in order to develop a classification scheme of business models that can form the basis for generalizations and eventually, for mid-range business model theories (Mäkinen \& Seppänen, 2007; Morris, Schindehutte, Richardson, \& Allen, 2006).

Recognising the level of generalizability is one way to distinguish one form of research from another. Research can also be distinguished according to research philosophy, approach, and strategy (Saunders, Lewis, \& Thornhill, 2003). In this paper, research is differentiated according to whether it is conceptual or empirical, and the relationships between conceptual and empirical research are explored along with the direction of reasoning of the empirical research.

\subsection{A Research Schema}

In this section of the paper, a business model research schema (BMRS) is proposed and in the following section, the BMRS is used to analyse business model research, both present and proposed. The BMRS is based on a scientific research schema that requires iterations of both conceptual and empirical research and a combination of deductive and inductive approaches in order to advance knowledge. Deductive reasoning begins with an abstract concept and then tests that concept with empirical evidence. Support for the concept is achieved if data collected from observations are consistent with the proposed concept. Once the concept has been tested, it can serve as a premise for the next cycle, and so on. This leads to the solid creation of concepts that are increasingly informed and worth pursuing (Shank, 2008). By contrast, inductive research, which aims to begin with no preconceived ideas of what will be found, creates grounded theory by beginning with data collection and then making generalizations and inferring theories based on the observations (Cavana, Delahaye, \& Sekaran, 2003; Neuman, 2003).

Knowledge is advanced through an iteration of deductive research and related inductive research linking 'the rational and the empirical, thought and fact, theory and practical experiment' (Bronowski 1951, p.31). This deductive-inductive cycle that is at the heart of scientific research (Ghent, 1966) is equally relevant to social sciences because it anchors the research in the reality which it is intended to serve (McKelvey, 1982).

In order to act in a scientific manner, in order to act in a human manner at all, two things are necessary: fact and thought. Science does not consist only of finding the facts; nor is it enough only to think, however rationally. The processes of science are characteristic of human action in that they move by the union of empirical fact and rational thought, in a way which cannot be disentangled. There is in science, as in all our lives, a continuous to and fro of factual discovery, then of thought about the implications of what we have discovered, and so back to the facts for testing and discovery - a step by step of experiment and theory [...]. (Bronowski 1951, p.30).

To bring business model research to the theorizing stage, the same scientific research approach is needed. The BMRS developed and proposed here is based on the deductive-inductive cycle for experimental research (Ghent, 1966). It shows the progression research must follow from initial conceptualization, to generalizations, to mid-range theory building. According to this schema, research begins with a notion that stems from research in related fields of study and motivated by observations of reality. This first phase of research is essentially pioneering research. It reflects the ideas and speculations of researchers who have very often transferred from other research areas, and it employs descriptive, analytic, and archival research strategies. Then, the resulting notion is tested using deductive empirical research and modified based on additional inductive empirical research (Ghent, 1966). The modified notion should be more realistic than the original one and it forms the basis of subsequent deductive research, and so on.

Deductive empirical research results inform efforts to refine and develop early conceptualizations; however, by its very nature, this research will only confirm or refute the propositions or hypotheses being tested; it will not uncover or determine that which it has not targeted. Inductive empirical research is exploratory in purpose and is approached with almost no preconceived ideas about what will be found. This empirical research is required to extend the boundaries of future analytic research.

Based on the original analytic and archival research and on the early deductive and inductive empirical research, the notions are developed and then tested using a further round of deductive empirical research. Each 
well-conceived round of conceptual and empirical research brings the research closer to theorizing: on the one hand, the results of deductive empirical research better match the anticipated results and the analytic explanations; on the other hand, predictions better match the results of inductive empirical research.

To move business model research towards theorizing, generalizations need to be made from which theories can be proposed and tested. The need to make generalizations about business models that in turn, can support mid-range theories of business models is an integral part of the BMRS which is illustrated in figure 1.

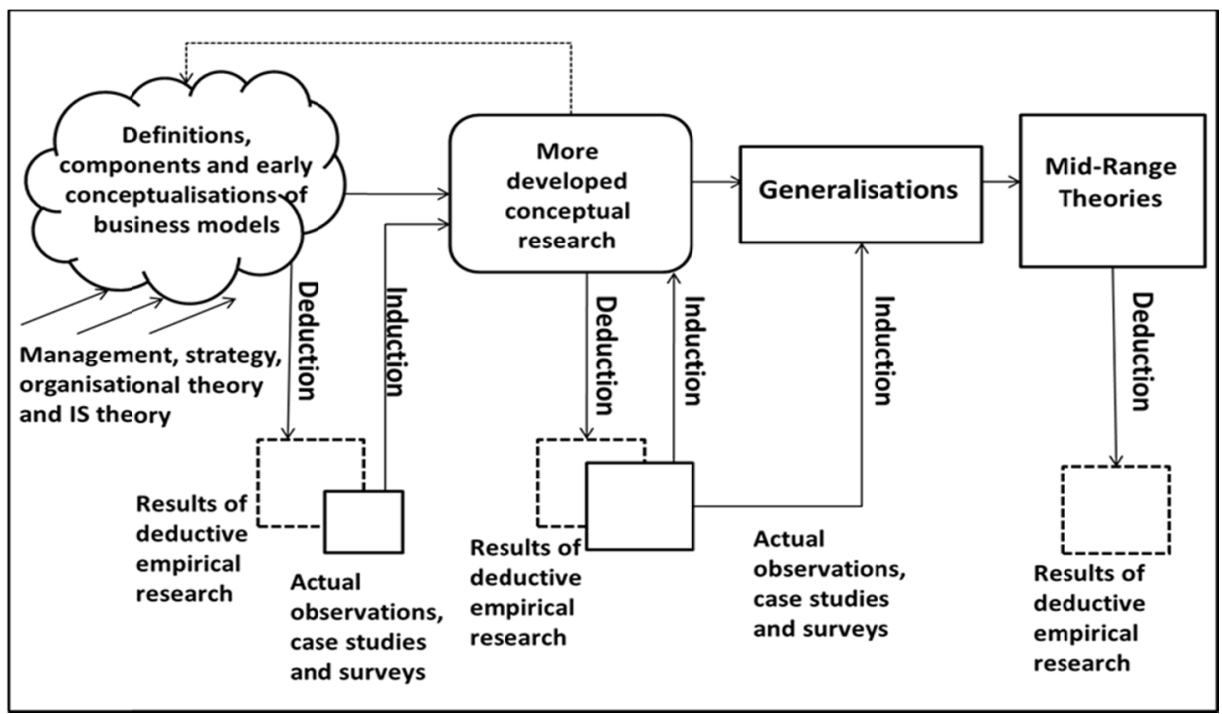

Figure 1. The Business Model Research Schema (BMRS) adapted from 'The Logic of Experimental Design' Source: Ghent 1966, p.18

The BMRS distinguishes research as either conceptual or empirical and if it is empirical, as inductive or deductive. The schema also provides a framework for acknowledging the progression of research from initial conceptualization to theorizing, it creates order in the research domain, and takes stock of what has gone before it. However, the BMRS does not distinguish between the different purposes and foci of research, all of which are required to move towards mid-range theorizing.

\section{Review of Literature Based on the Business Model Research Schema}

Archival and analytic research on business models began to appear in scholarly journals in the mid-1990s. The early research was motivated by ad hoc observations of business activity and, as shown in figure 1, the archival input derives from closely related but already established research areas such as management, organizational, strategy, and information systems theory. Definitions and constructs (Hamel, 2000; Mahadevan, 2000; Tapscott, Ticoll, \& Lowy, 2000) as well as typologies of business models (Alt \& Zimmermann, 2001; Pant \& Ravichandran, 2001; Patel, 2002; Timmers, 1998; Weill \& Vitale, 2001) dominate the early research with isolated attempts to integrate the concept with other management issues such as change management (Betz, 2002) and adoption factors (Elliot, 2002). Several definitions of the business model have been proposed to provide a frame of reference, focusing attention on the aspects thought to be relevant (for exhaustive reviews, see Al-Debei \& Avison, 2010; Nielsen, 2011; Zott et al. 2011; Fielt, 2013). This phase brought about an increased awareness of the relationship between the business model and the value creation process (Magretta, 2002; Rappa, 2001).

The conceptual research formed the basis of empirical studies that used the business model to classify enterprises (see Fisken \& Rutherford, 2002; Weill \& Vitale, 2002; Palmer \& Lindermann, 2003), explore the relationship between the business model and enterprise performance (see Fisken \& Rutherford, 2002 and Li, 2002), and identify business model innovation (see Porra; 2000; Chan-Olmsted \& Ha, 2003).

By 2003, approximately, the business model concept had attained general acceptance as a useful management concept and the second phase of archival and analytic research emerged from earlier conceptualizations of the business model (Gordijn, Osterwalder, \& Pigneur, 2005; Morris et al., 2005; Shafer, Smith, \& Linder, 2005). Frameworks and ontologies of business models were then proposed as a means of representing and explaining 
relationships between business model components. This stage of research progression equates to the "more developed conceptual research' part of the BMRS shown in figure 1.

In parallel to the concept-focused research being conducted, there were studies that looked at the relationships between the business model and other management phenomena such as change management (Chaharbaghi, Fendt, \& Willis, 2003; Voelpel, Leibold, Tekie, \& Von Krogh, 2005), adoption factors (Afuah, 2004), evaluation (Mäkinen \& Seppänen, 2007), strategy (Casadesus-Masanell \& Ricart, 2010; Seddon, Lewis, Freeman, \& Shanks, 2004), innovation (Chesbrough, 2010; Gambardella \& McGahan, 2010; Giesen, Berman, Bell, \& Blitz, 2007), and meta-analysis (Morris et al., 2006; Osterwalder \& Pigneur, 2010; Pateli \& Giaglis, 2004; Shafer et al., 2005). Subsequent deductive (Kauffman \& Wang, 2008; Rasheed, 2009; Rédis, 2009; Zott \& Amit, 2007) and inductive (Glick, 2008; Koh, Gunasekaran, \& Saad, 2005; Mair \& Schoen, 2007) empirical research was mostly industry specific and concerned with the evaluation and classification of business models.

Many specific arbitrary classifications were proposed, some of which make no explicit reference to, or use only a few, classification criteria (see, for example, Bambury, 1998; Betz, 2002; Chen, 2003; Dubosson-Torbay, Osterwalder, \& Pigneur, 2002; Mäkinen \& Seppänen, 2007; Timmers, 1998). These typologies were used to describe the business models that existed or were designed to meet the immediate needs of researchers (Fielt, 2013). Thus, it is not surprising that these typological classification schemes are rarely useful for other purposes and are mostly inconsistent with one another (Lambert, 2015). Numerous deductively derived business model classifications were conceived and then data was collected to support the existence of the typologies. In contrast, inductive empirical classification research was scant.

A further round of conceptual (Baden-Fuller \& Haefliger, 2013; Cavalcante, Kesting, \& Ulhøi, 2011; DaSilva \& Trkman, 2014; Morris, 2013), deductive (Bock \& George, 2011; Bock, Opsahl, George, \& Gann, 2012; Visnjic Kastalli \& Van Looy, 2013; Wei, Yang, Sun, \& Gu, 2014) and inductive research (Aspara, Lamberg, Laukia, \& Tikkanen, 2011; Cavalcante, 2014; Hacklin \& Wallnöfer, 2012; Taran, Boer, \& Lindgren, 2015; Velu \& Stiles, 2013) followed. Literature reviews (Lambert \& Davidson, 2013; Zott et al., 2011) that frame the state of the art in business model research and identify related research agendas (Arend, 2013; Baden-Fuller \& Mangematin, 2013; Eckhardt, 2013; Zott \& Amit, 2013) have emerged to provide an account of existing research and to guide future research.

The research themes that have surfaced in recent years include the following:

- the business model as a new and distinct level and unit of analysis in strategic, organizational and entrepreneurship research (Zott et al., 2011);

- the business model as a means of providing a broad system-level approach to value creation for all stakeholders (Zott et al., 2011);

- $\quad$ the business model as the basis for enterprise classification (Lambert \& Davidson, 2013);

- $\quad$ the business model as a contributor to business success (Lambert \& Davidson, 2013);

- business model innovation of itself (Lambert \& Davidson, 2013; Schneider \& Spieth, 2013; Spieth, Schneckenberg, \& Ricart, 2014).

However, despite several cycles of conceptual-deductive-inductive research covering a range of topics, business model theories have yet to materialise. With reference to the BMRS depicted in figure 1, the body of research finds itself in a loop of conceptualisation and support of inductive-deductive empirical research. To progress towards generalisations about homogeneous groups of business models, an inductively derived, general classification is required (Groth \& Nielsen, 2015; Lambert, 2015). Because mid-range theory building is based on generalizations about homogeneous groups of objects, the lack of a general classification scheme for business models represents a significant gap in the research.

\section{Opportunities for Future Research}

It is evident from the foregoing that opportunities for business model research abound. There is still no universally accepted definition of the term 'business model' (Arend, 2013) and the overlap of the business model concept with established concepts and theories, such as strategy, activity system and entrepreneurial opportunities, needs to be addressed (Lambert \& Davidson, 2013; Zott \& Amit, 2013).

Ongoing opportunities exist to challenge and move the existing business model conceptualizations through analytical, conceptual, normative, and positive empirical research. Deductive research that tests the efficacy of the frameworks and models and inductive research that explores relationships between business models and other 
phenomena for explanatory and predictive purposes is also required. Without claiming to represent a comprehensive view, a set of interrelated topics for future research is now presented.

\subsection{Business Model Design}

- $\quad$ Design and test appropriate tools, managerial practices and methods to support business model designs that (a) are internally consistent, (b) are, as a whole, consistent with other elements that characterize the enterprise such as its strategy, its activity system, its value chain, its ecosystem or its internal organization hierarchies, roles, and incentives, and (c) are consistent with the business models of the entities that interact with the focal enterprise (Zott \& Amit, 2013). This can be achieved mainly through normative and related, inductive empirical research;

- $\quad$ Explore, through empirical means, how and why business models come to light, i.e., which parts of the design process are planned and which ones are emergent (Zott \& Amit, 2013), what levers and barriers enable or hinder the process of business model design;

- $\quad$ Analyse the nature and content of business models that transcend time and industry boundaries (Taran et al., 2016), through conceptual, empirical, and analytical research. The results of such research can aid decision makers in designing or innovating their business models.

\subsection{Business Model Implementation}

- Conduct normative research and apply related inductive research to design and test tools and managerial procedures to support practitioners in business model implementation;

- Investigate, through inductive and deductive empirical research, the relationships between business model implementation and organization strategy, activity systems, value chains and ecosystems;

- Explore, mainly through inductive empirical research, the levers and the barriers that can enable or hinder the process of business model implementation;

- Explore, mainly through inductive empirical research, how multiple business models can be implemented and managed simultaneously (Arend, 2013).

\subsection{Business Model Effects}

Explain how a business model can become a source of competitive advantage, and how it can assist in planning and predicting upcoming forms of competitive advantage (DaSilva \& Trkman, 2014). This can be achieved mainly through conceptual and deductive empirical research;

Determine, through deductive empirical research, the relationships between business models and organization performance (Lüttgens \& Montemari, 2016);

Explore, mainly through inductive empirical research, the unintended and unforeseen effects that occur within the organization when new business models are adopted (Arend, 2013);

\subsection{Business Model Measurement and Disclosure}

Explore the interaction between business models and performance measurement, i.e., how the business model can be used as a platform to extract key performance indicators and key risk indicators. This can be achieved mainly through inductive empirical research;

Determine how the business model should be explained in corporate reporting (such as Integrated Reporting (International Integrated Reporting Council (IIRC), 2013)) and explore the interaction between business models and corporate reporting, mainly through normative research and related inductive empirical research.

\subsection{Business Model Change/Innovation/Renewal}

Through conceptual and analytical research, clarify the meaning of the frequently used term 'business model innovation', and determine what changes constitute a business model innovation (DaSilva \& Trkman, 2014);

Design and test management tools and practices to support the business model innovation process (Schneider \& Spieth, 2013) through normative and related inductive empirical research;

Explore, through empirical research, the sources and antecedents of business model innovation (Spieth et al., 2014); how, when and why business models require transformation (Arend, 2013) and the levers and barriers that enable or hinder the process of business model innovation;

Identify the impacts of business model innovation on a firm's capabilities and performance (Schneider \& Spieth, 2013), through deductive and inductive empirical research; 
Explore, mainly through inductive empirical research, how purposeful design and planning, evolutionary dynamics, and environmental and social processes shape business models (Zott \& Amit, 2013).

\section{Conclusions}

Business model research currently finds itself in its pre-paradigm period as an immature science that lacks consensus and in which 'competing schools of thought possess differing procedures, theories, even metaphysical presuppositions' (Bird, 2008). Many definitions of business models have been proposed over the last decade and a half and, although a settling of the terms seems to be gradually emerging, there is still no universally accepted definition, to date. The persistence of conceptual differences inhibits research that uses the business model as a vehicle to collect information about other phenomena. In addition, the relationships between business models and various organization abstraction levels (e.g. strategy, activity systems, value chains, ecosystems) still need to be addressed. The literature reveals a maturing of the research field that includes a range of subject matter concerning the business model concept per se and concerning the relationships between business models and other phenomena, but the body of research remains underdeveloped and there is an absence of order that obscures the path to the building of business model theories. In this article the authors have made a contribution by providing some order to the research field in the form of the BMRS and the subsequent analysis of existing research.

The BMRS emphasizes the need for both inductive and deductive empirical research to progress towards business model theory building. In a relatively young research field that is bereft of mid-range theory, inductive, exploratory research, in particular with respect to classification, is needed to provide a theoretical foundation grounded in observation. The development of a unifying business model concept that can facilitate the construction of a general business model classification scheme which, in turn, can provide the basis for generalizations is integral to mid-range theory building.

Avenues for future research have been organized around five key themes to encourage progressive cycles of conceptual-deductive-inductive research and ultimately, theorizing. It remains to be seen whether theories of business models emerge from a schema such as the one proposed here and whether a general classification will eventually enable business model generalizations, but they are certainly topics worthy of future research.

\section{References}

Afuah, A. (2004). Business models: A strategic management approach. New York, NY: McGraw-Hill Irwin.

Al-Debei, M. M., \& Avison, D. (2010). Developing a unified framework of the business model concept. European Journal of Information Systems, 19(3), 359-376. http://doi.org/doi:10.1057/ejis.2010.21

Alt, R., \& Zimmermann, H.-D. (2001). Introduction to special section-Business models. Electronic Markets The International Journal, 11(1), 1-13.

Arend, R. (2013). The business model: Present and future - Beyond a skeumorph. Strategic Organization, 11(4), 390-402. http://doi.org/10.1177/1476127013499636

Aspara, J., Lamberg, J.A., Laukia, A., \& Tikkanen, H. (2011). Strategic management of business model transformation: Lessons from Nokia. Management Decision, 49(4), 622-647. http://doi.org/http://dx.doi.org/10.1108/00251741111126521

Ayres, L. (2008). Grand theory. In L. Given (Ed.), The SAGE Encyclopedia of Qualitative Research Methods (pp. 374-375). Thousand Oaks, CA: Sage Publications.

Bacharach, S. B. (1989). Organizational theories: Some criteria for evaluation. Academy of Management Review, 14(4), 496-515.

Baden-Fuller, C., \& Haefliger, S. (2013). Business Models and Technological Innovation. Long Range Planning, 46(6), 419-426. http://doi.org/http://dx.doi.org/10.1016/j.lrp.2013.08.023

Baden-Fuller, C., \& Mangematin, V. (2013). Business models: A challenging agenda. Strategic Organization, 11(4), 418-427.

Bailey, K. D. (1994). Typologies and Taxonomies: An Introduction to Classification Techniques. Los Angeles: Sage Publications.

Bambury, P. (1998). A taxonomy of internet commerce. First Monday, 3(10).

Berg, B., \& Lune, H. (2012). Qualitative Research Methods for the Social Sciences (Eight Edit). Upper Saddle River, NJ: Pearson.

Betz, F. (2002). Strategic business models. Engineering Management Journal, 14(1), 21-28. 
Bird, A. (2008). Thomas Kuhn. In Stanford Encyclopedia of Philosophy.

Bock, A. J., \& George, G. (2011). The business model in practice and its implications for entrepreneurship research. Entrepreneurship: Theory \& http://doi.org/10.1111/j.1540-6520.2010.00424.x

Bock, A. J., Opsahl, T., George, G., \& Gann, D. M. (2012). The effects of culture and structure on strategic flexibility during business model innovation. Journal of Management Studies, 49(2), 279-305. http://doi.org/10.1111/j.1467-6486.2011.01030.x

Bocken, N. M. P., Short, S. W., Rana, P., \& Evans, S. (2014). A literature and practice review to develop sustainable business model archetypes. Journal of Cleaner Production, 65, 42-56. http://doi.org/10.1016/j.jclepro.2013.11.039

Bronowski, J. (1951). The common sense of science. London: Heineman Educational Books Ltd.

Casadesus-Masanell, R., \& Ricart, J. (2010). From strategy to business models and onto Tactics. Long Range Planning, 43(2-3), 195-215. http://doi.org/10.1016/j.lrp.2010.01.004

Cavalcante, S. A. (2013). Understanding the impact of technology on firms' business models. European Journal of Innovation Management, 16(3), 285-300. http://doi.org/http://dx.doi.org/10.1108/EJIM-10-2011-0085

Cavalcante, S. A. (2014). Preparing for business model change: the "pre-stage" finding. Journal of Management \& Governance, 18(2), 449-469. http://doi.org/10.1007/s10997-012-9232

Cavalcante, S., Kesting, P., \& Ulhøi, J. (2011). Business model dynamics and innovation: (re)establishing the missing linkages. Management $\quad$ Decision, 1327-1342. http://doi.org/http://dx.doi.org/10.1108/00251741111163142

Cavana, R. Y., Delahaye, B. L., \& Sekaran, U. (2003). Applied business research: qualitative and quantitative methods. Milton Queensland: John Wiley \& Sons Australia.

Chaharbaghi, K., Fendt, C., \& Willis, R. (2003). Meaning, legitimacy and impact of business models in fast-moving environments. Management $372-382$. http://doi.org/https://doi.org/10.1108/00251740310468013

Chen, S. (2003). The real value of "e-business models." Business Horizons, 46(6), 27-33. http://doi.org/10.1016/S0007-6813(03)00085-5

Chesbrough, H. (2007). Why companies should have open business models. MIT Sloan Management Review, $48(2), 22-28$.

Chesbrough, H. (2010). Business model innovation: Opportunities and barriers. Long Range Planning, 43(2-3), 354-363. http://doi.org/10.1016/j.lrp.2009.07.010

Cooper, D., \& Schindler, P. (2000). Business research methods (7th Editio). New York, NY: McGraw-Hill Irwin.

DaSilva, C. M., \& Trkman, P. (2014). Business model: What it is and what it is not. Long Range Planning, 47(6), 379-389. http://doi.org/10.1016/j.lrp.2013.08.004

Demil, B., \& Lecocq, X. (2010). Business model evolution: In search of dynamic consistency. Long Range Planning, 43(2-3), 227-246. http://doi.org/10.1016/j.lrp.2010.02.004

Doty, D. H., \& Glick, W. H. (1994). Typologies as a unique form of theory building: Toward improved understanding and modelling. Academy of Management Review, 19(2), 230-251. http://doi.org/10.5465/AMR.1994.9410210748

Dubosson-Torbay, M., Osterwalder, A., \& Pigneur, Y. (2002). E-business model design, classification, and measurements. Thunderbird International Business Review, 44(1), 5-23.

Eckhardt, J. T. (2013). Opportunities in business model research. Strategic Organization, 11(4), 412-417. http://doi.org/10.1177/1476127013511059

Elliot, S. (2002). Electronic commerce: B2C strategies and models. West Sussex: John Wiley \& Sons. http://doi.org/10.1108/14626000310489871

Fielt, E. (2013). Conceptualising business models: Definitions, frameworks and classifications. Journal of Business Models, 1(1), 85-105. http://doi.org/http://dx.doi.org/10.5278/ojs.jbm.v1i1.706

Gambardella, A., \& McGahan, A. M. (2010). Business-model innovation: General purpose technologies and their implications for industry structure. Long Range Planning, 43(2-3), 262-271. 
http://doi.org/10.1016/j.lrp.2009.07.009

Gassmann, O., Frankenberger, K., \& Csik, M. (2014). The Business Model Navigator (1st ed.). Harlow: Pearson.

Ghent, A. W. (1966). The logic of experimental design in the biological sciences. Bioscience, 16, 17-22.

Giesen, E., Berman, S. J., Bell, R., \& Blitz, A. (2007). Three ways to successfully innovate your business model. Strategy \& Leadership, 35(6), 27-33. http://doi.org/10.1108/10878570710833732

Glick, J. L. (2008). Biotechnology business models work: Evidence from the pharmaceutical marketplace. Journal of Commercial Biotechnology, 14(2), 106-117.

Gordijn, J., Osterwalder, A., \& Pigneur, Y. (2005). Comparing two business model Ontologies for designing e-business models and value constellations. In 18th Bled eConference - eIntegration in Action (pp. 1-17). Bled, Slovenia.

Groth, P., \& Nielsen, C. (2015). Constructing a business model taxonomy : Using statistical tools to generate a valid and reliable business model taxonomy. Journal of Business Models, 3(1), 4-21. http://doi.org/http://dx.doi.org/10.5278/ojs.jbm.v3i1.1211

Hacklin, F., \& Wallnöfer, M. (2012). The business model in the practice of strategic decision making: Insights from a case study. Management Decision, 50(2), 166-188. http://doi.org/http://dx.doi.org/10.1108/00251741211203515

Hamel, G. (2000). Leading the revolution. Boston: Harvard Business School Press.

International Integrated Reporting Council (IIRC). (2013). The International $<I R>$ Framework. London: International Integrated Reporting Council.

Kauffman, R. J., \& Wang, B. (2008). Tuning into the digital channel: evaluating business model characteristics for Internet firm survival. Information Technology and Management, 9(3), 215-232. http://doi.org/10.1007/s10799-008-0040-3

Koh, S. C. L., Gunasekaran, A., \& Saad, S. M. (2005). A business model for uncertainty management. Benchmarking: An International Journal, 12(4), 383-400. http://doi.org/10.1108/14635770510609042

Lambert, S. C. (2015). The importance of classification to business model research. Journal of Business Models, 3(1), 49-61. http://doi.org/http://dx.doi.org/10.5278/ojs.jbm.v3i1.1045

Lambert, S. C., \& Davidson, R. A. (2013). Applications of the business model in studies of enterprise success, innovation and classification: An analysis of empirical research from 1996 to 2010. European Management Journal, 31(6), 668-681. http://doi.org/10.1016/j.emj.2012.07.007

Llewelyn, S. (2003). What counts as "theory" in qualitative management and accounting research? Introducing five levels of theorizing. Accounting, Auditing \& Accountability Journal, 16(4), 662-708. http://doi.org/10.1108/09513570310492344

Lüttgens, D., \& Montemari, M. (2016). Editorial: New Ways of Developing and Analyzing Business Model Innovation. Journal of Business http://doi.org/http://dx.doi.org/10.5278/ojs.jbm.v4i3.1875

Magretta, J. (2002). Why business models matter. Harvard Business Review, 80(5), 86-92. http://doi.org/10.1002/1099-0690(200112)2001:23<4391::AID-EJOC4391>3.0.CO;2-D

Mahadevan, B. (2000). Business models for internet-based e-commerce: An anatomy. California Management Review, 42(4), 55-70. http://doi.org/Article

Mair, J., \& Schoen, O. (2007). Successful social entrepreneurial business models in the context of developing economies: An explorative study. International Journal of Emerging Markets, 2, 54-68. http://doi.org/10.1108/17468800710718895

Mäkinen, S., \& Seppänen, M. (2007). Assessing business model concepts with taxonomical research criteria: A $\begin{array}{lllll}\text { preliminary study. Management Research } & \text { News, }\end{array}$ http://doi.org/10.1108/01409170710823458

McGrath, R. G. (2010). Business models: A discovery driven approach. Long Range Planning, 43(2-3), 247-261. http://doi.org/10.1016/j.lrp.2009.07.005

McKelvey, B. (1982). Organizational Systematics: Taxonomy, Evolution, Classification. Berkeley: University of California Press. 
Mezzich, J. E., \& Solomon, H. (1980). Taxonomy and Behavioral Science: Comparative Performance of Grouping Methods. London: Academic Press Inc.

Montemari, M., \& Chiucchi, M. S. (2017). Enabling Intellectual Capital Measurement Through Business Model Mapping: The Nexus Case. In J. Guthrie, J. Dumay, F. Ricceri, \& C. Nielsen (Eds.), The Routledge Companion to Intellectual Capital. London: Routledge.

Morgan, C., \& Wildemuth, B. (2009). Questions related to theory. In B. Wildemuth (Ed.), Applications of Social Science Research Methods to Questions in Information and Library Science (pp. 40-47). Westport, CT: Libraries Unlimited.

Morris, L. (2013). Business model warfare. Journal of Business Models, 1(1), 13-37. http://doi.org/http://dx.doi.org/10.5278/ojs.jbm.v1i1.617

Morris, M., Schindehutte, M., \& Allen, J. (2005). The entrepreneur's business model: Toward a unified perspective. Journal of Business Research, 58(6), 726-735. http://doi.org/10.1016/j.jbusres.2003.11.001

Morris, M., Schindehutte, M., Richardson, J., \& Allen, J. (2006). Is the business model a useful strategic concept? Conceptual, theoretical, and empirical insights. Journal of Small Business Strategy, 17(1), 27-50.

Neuman, W. L. (2003). Social research methods: Qualitative and quantitative approaches (5th Editio). Boston: Pearson Education Inc. http://doi.org/10.2307/3211488

Nielsen, C. (2011). Conceptualizing, analyzing and communicating the business model. In J. A. Beckmann (Ed.), Business Models: Design, Dynamics and Implementation (pp. 37-62). New York, NY: Nova Science Publishers.

Nielsen, C., \& Montemari, M. (2012). The role of human resources in business model performance: The case of network-based companies. Journal of Human Resource Costing \& Accounting, 16(2), 142-164. http://doi.org/10.1108/14013381211284254

Nielsen, C., Roslender, R., \& Bukh, P. N. (2009). Intellectual capital reporting: Can a strategy perspective solve accounting problems? In M. Lytras \& P. Ordóñez de Pablos (Eds.), Knowledge Ecology in Global Business: Managing Intellectual Capital (pp. 174-191). Hershey: Information Science Reference. http://doi.org/10.4018/978-1-60566-270-1.ch011

Osterwalder, A., \& Pigneur, Y. (2010). Business model generation: A handbook for visionaries, game changers, and challengers. Hoboken: John Wiley \& Sons.

Pant, S., \& Ravichandran, T. (2001). A framework for information systems planning for e-business. Logistics Information Management, 14(1/2), 85-99. http://doi.org/10.1108/09576050110362474

Patel, N. W. (2002). Emergent forms of IT governance to support global e-business models. JITTA: Journal of Information Technology Theory and Application, 4(2), 33-48.

Pateli, A. G., \& Giaglis, G. M. (2004). A research framework for analysing eBusiness models. European Journal of Information Systems. https://doi.org/10.1057/palgrave.ejis.3000513

Popper, K. (1959). The logic of scientific discovery. London: Hutchinson \& Co Ltd.

Rappa, M. (2001). Managing the digital enterprise - Business models on the web. Retrieved September 20, 2015, from http://digitalenterprise.org/models/models.html

Rasheed, H. (2009). Contrasting e-commerce business models: Performance implications for small enterprises. Journal of Developmental Entrepreneurship, 14(1), 89-101. http://doi.org/10.1142/S1084946709001168

Rédis, J. (2009). The impact of business model characteristics on IT firms' performance. International Journal of Business, 14(4), 291-307.

Sabatier, V., Mangematin, V., \& Rousselle, T. (2010). From recipe to dinner: Business model portfolios in the European biopharmaceutical industry. Long Range Planning, 43(2-3), 431-447. http://doi.org/10.1016/j.lrp.2010.02.001

Saunders, M., Lewis, P., \& Thornhill, A. (2003). Research methods for business students (3rd ed.). Essex: Pearson Education.

Schneider, S., \& Spieth, P. (2013). Business model innovation: Towards an integrated future research agenda. International Journal of Innovation Management, 17(1), 1-34. http://doi.org/10.1142/S136391961340001X

Seddon, P., Lewis, G., Freeman, P., \& Shanks, G. (2004). The case for viewing business models as abstractions 
of strategy. Communications of the Association for Information Systems, 13, 427-442.

Shafer, S. M., Smith, H. J., \& Linder, J. C. (2005). The power of business models. Business Horizons, 48(3), 199-207. http://doi.org/10.1016/j.bushor.2004.10.014

Shank, G. (2008). Deduction. In L. Given (Ed.), The SAGE Encyclopedia of Qualitative Research Methods (pp. 208-209). Thousand Oaks, CA: Sage Publications.

Silverman, D. (2006). Interpreting qualitative data: Methods for analyzing talk, text and interaction. Thousand Oaks, CA: Sage Publications.

Spieth, P., Schneckenberg, D., \& Ricart, J. E. (2014). Business model innovation - State of the art and future challenges for the field. R\&D Management, 44(3), 237-247. http://doi.org/10.1111/radm.12071

Steininger, D. M., Trenz, M., \& Veit, D. J. (2013). Building taxonomies in IS and management. A systematic approach based on content analysis. In 11th International Conference on Wirtschaftsinformatik. Leipzig, Germany.

Tapscott, D., Ticoll, D., \& Lowy, A. (2000). Digital capital: Harnessing the power of business webs. Boston: Harvard Business School Press. http://doi.org/10.1145/336228.336231

Taran, Y., Boer, H., \& Lindgren, P. (2015). A business model innovation typology. Decision Sciences, 46(2), 301-331. http://doi.org/10.1111/deci.12128

Taran, Y., Nielsen, C., Montemari, M., Thomsen, P., \& Paolone, F. (2016). Business model configurations: A five-V framework to map out potential innovation routes. European Journal of Innovation Management, 19(4), 492-527. http://doi.org/https://doi.org/10.1108/EJIM-10-2015-0099

Teece, D. J. (2010). Business models, business strategy and innovation. Long Range Planning, 43(2-3), 172-194. http://doi.org/10.1016/j.lrp.2009.07.003

Timmers, P. (1998). Business models for electronic markets. Journal on Electronic Markets, 8(2), 3-8.

Velu, C., \& Stiles, P. (2013). Managing decision-making and cannibalization for parallel business models. Long Range Planning, 46(6), 443-458. http://doi.org/10.1016/j.lrp.2013.08.003

Visnjic Kastalli, I., \& Van Looy, B. (2013). Servitization: Disentangling the impact of service business model innovation on manufacturing firm performance. Journal of Operations Management, 31(4), 169-180. http://doi.org/10.1016/j.jom.2013.02.001

Voelpel, S., Leibold, M., Tekie, E., \& Von Krogh, G. (2005). Escaping the red queen effect in competitive strategy: Sense-testing business models. European Management Journal, 23(1), 37-49. http://doi.org/10.1016/j.emj.2004.12.008

Wei, Z., Yang, D., Sun, B., \& Gu, M. (2014). The fit between technological innovation and business model design for firm growth: evidence from China. $R \& D$ Management, 44(3), 288-305. http://doi.org/10.1111/radm.12069

Weill, P., \& Vitale, M. R. (2001). Place to Space: Migrating to eBusiness Models. Boston: Harvard Business School Press Books. http://doi.org/10.1109/EMR.2003.1267030

Zott, C., \& Amit, R. (2007). Business model design and the performance of entrepreneurial firms. Organization Science, 18(2), 181-199. http://doi.org/10.1287/orsc.1060.0232

Zott, C., \& Amit, R. (2013). The business model: A theoretically anchored robust construct for strategic analysis. Strategic Organization, 11(4), 403-411. http://doi.org/10.1177/1476127013510466

Zott, C., Amit, R., \& Massa, L. (2011). The business model: Recent developments and future research. Journal of Management, 37(4), 1019-1042. http://doi.org/10.1177/0149206311406265

\section{Copyrights}

Copyright for this article is retained by the author(s), with first publication rights granted to the journal.

This is an open-access article distributed under the terms and conditions of the Creative Commons Attribution license (http://creativecommons.org/licenses/by/4.0/). 